\title{
BROMATOLOGICAL CHARACTERISTICS OF Macrotyloma axillare AS A FUNCTION OF COMBINED SUPPLY OF PHOSPHORUS AND CALCIUM
}

\author{
CARACTERÍSTICAS BROMATOLÓGICAS DE Macrotyloma axillare EM FUNÇÃO \\ DO SUPRIMENTO COMBINADO DE FÓSFORO E CÁLCIO
}

\author{
Karina BATISTA ${ }^{\mathbf{1}}$; Alessandra Aparecida GIACOMINI ${ }^{\mathbf{1}}$; Waldssimiler Teixeira de MATTOS ${ }^{\mathbf{1}}$; \\ Luciana GERDES ${ }^{1}$; Ivani Pozar OTSUK ${ }^{1}$; Flávia Maria de Andrade GIMENES ${ }^{1}$ \\ 1. APTA, Instituto de Zootecnia, Nova Odessa, SP, Brazil. batistakarin@gmail.com
}

\begin{abstract}
The supply of nutrients to forage legumes is significant for their nutritional quality. The study aimed to evaluate the bromatological characteristics of the legume Macrotyloma axillare in response to the combined application of phosphorus and calcium. The study was conducted in a greenhouse on a Red Yellow Ultisol. A fractionated $5^{2}$ factorial was used, with 13 different combinations of phosphorus and calcium application rates (P-Ca): 0-0; 0-20; 0-40; $100-10 ; 100-30 ; 200-0 ; 200-20 ; 200-40 ; 300-10 ; 300-30 ; 400-0 ; 400-20$; and 400-40 mg dm ${ }^{-3}$. Experimental units were set in a randomized block design, with four replications. Neutral detergent fiber (NDF), acid detergent fiber (ADF), hemicellulose, cellulose, lignin, and crude protein (CP) in the leaves and branches were determined in two harvests. In both harvests of the legume we observed that the $\mathrm{ADF}$, hemicellulose, cellulose, and lignin contents in the leaves did not show isolated or combined responses to phosphorus and calcium rates. It was concluded that the combined supply of phosphorus and calcium did not interfere in the nutritional quality of the legume. Calcium supplied alone interfered only

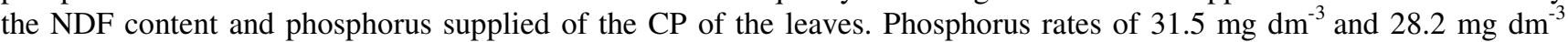
were responsible for the lower NDF content in the leaves and the higher hemicellulose content in the branches, respectively.
\end{abstract}

KEYWORDS: Combination of Nutrients. Crude protein. Fibers. Forage legume. Sustainable farming.

\section{INTRODUCTION}

In tropical areas, a major challenge faced by cattle farmers is providing adequate nutrition for their animals during the dry season, when pasture, grain residues, and corn husk have poor nutritional quality. An alternative means of improving animal feeding during this period is the use of forage legumes (BARROS-RODRÍGUEZ et al., 2014). The use of forage legumes in pasture has been recommended because of their ability to fix atmospheric nitrogen, allowing an improved availability of nitrogen for plants in consortium or in succession (ROSCHER et al., 2011). In this context, the inclusion of legumes in pasture can improve the biomass production quality and provide forage support for a long period (LÜSCHER et al., 2014).

Among the forage legumes with potential use in animal production systems in tropical countries there is Macrotyloma axillare, a species from South African that is very tolerant to drought and it can survive in situations for up to 8 months in situations with of very dry winter-spring weather and during hot and dry summer periods (BLUMENTHAL; STAPLES, 1993). However, in order to make this legume suitable for animal production systems, its qualitative evaluation is needed to determine whether it is capable of providing a diet which is balanced and rich in protein and energy, as well as to identify its potential toxicity potential for animals (CHAUDHRY, 2008).

In the qualitative evaluation of forage legumes, studying the crude protein $(\mathrm{CP})$, neutral detergent fiber (NDF), and acid detergent fiber (ADF) contents is key, as these parameters can influence legume consumption by animal species (OLIVO et al., 2009). Hemicellulose is part of the NDF and cellulose represents the bulk of ADF (CAMPOS et al., 2016). Lignin is an amorphous structural component, which seems to have a 'cementing' function. Lignin combined with cellulose and hemicellulose forms a ligno-cellulosic complex, making those carbohydrates unavailable for degradation by microorganisms (SARKAR et al., 2009; CHEN, 2014).

The use of forage legumes without prior study can result in low animal production, due to lack of appropriate indications regarding plant nutrition for maximizing animal performance (SITA et al., 2017). From this perspective, an adequate supply of nutrients to forage legumes is of great importance for their quality. Applied individually, phosphorus and calcium interfere with nodulation of forage legumes, root growth, senescence, and foliar abscission, and consequently with their growth (SULIEMAN et al., 2013; WHITE; BROADLEY, 2003; YANG et al., 2012). 
In legumes, the total composition of free amino acids in the phloem is affected by phosphorus deficiency. Additionally, phosphorus deficiency has a strong influence on the nodule carbon metabolites content (SULIEMAN et al., 2013). Calcium is required for various structural roles in the cell wall and membranes is a counter cation for inorganic and organic anions in the vacuole, and the cytosolic $\mathrm{Ca}^{2+}$ concentration $\left(\left[\mathrm{Ca}^{2+}\right] \mathrm{cyt}\right)$ is an obligate intracellular messenger coordinating responses to numerous developmental cues and environmental challenges (WHITE; BROADLEY, 2003; YANG et al., 2012). However, there is a lack of studies on the interference between these nutrients when used in combination in terms of providing forage legumes of adequate nutritional quality.

Given the above, this study evaluated the bromatological characteristics of the Macrotyloma axillare legume in response to the combined application of phosphorus and calcium.

\section{MATERIAL AND METHODS}

The experiment was carried out in a greenhouse, located in Nova Odessa, São Paulo, Brazil, during the period from August to December 2015, in a Red Yellow Ultisol (SANTOS et al., 2006) and with the forage species Macrotyloma axillare, access NO279 (Macrotyloma legume). The study was conducted under controlled conditions in order to avoid interference of climatic conditions and to guarantee the adequate water supply and temperature for plant growth. The average temperature in the greenhouse varied from 32.54 at $37.73{ }^{\circ} \mathrm{C}$.
Soil samples (0-20 cm layer) were sent for analysis before starting the experiment. Granulometric analysis (GEE; BAUDER, 1996) showed the following average results: total sand = $560 \mathrm{~g} \mathrm{~kg}^{-1}$, silt $=162 \mathrm{~g} \mathrm{~kg}^{-1}$, and clay $=278 \mathrm{~g} \mathrm{~kg}^{-1}$. According to these results, the soil was classified as having a medium texture. Chemical analysis of the soil after drying and sieving gave the following average results: $\mathrm{pH}$ in $\mathrm{CaCl}_{2}=4.4$; organic matter content $=25.0 \mathrm{~g} \mathrm{dm}^{-3} ; \mathrm{P}($ resin $)=24.0 \mathrm{mg} \mathrm{dm}^{-3} ; \mathrm{K}$ $($ resin $)=2.8 \mathrm{mmol}_{\mathrm{c}} \mathrm{dm}^{-3} ; \mathrm{Ca}($ resin $)=17.0 \mathrm{mmol}_{\mathrm{c}}$ $\mathrm{dm}^{-3}, \mathrm{Mg}($ resin $)=8.0 \mathrm{mmol}_{\mathrm{c}} \mathrm{dm}^{-3} ; \mathrm{Al}=3.0 \mathrm{mmol}_{\mathrm{c}}$ $\mathrm{dm}^{-3} ; \mathrm{H}+\mathrm{Al}=38.0 \mathrm{mmol}_{\mathrm{c}} \mathrm{dm}^{-3} ; \mathrm{SO}_{4}=3.0 \mathrm{mg} \mathrm{dm}^{-3} ;$ $\mathrm{SB}=28.0 \mathrm{mmol}_{\mathrm{c}} \mathrm{dm}^{-3} ; \mathrm{CEC}=66.0 \mathrm{mmol}_{\mathrm{c}} \mathrm{dm}^{-3} ; \mathrm{V}$ $=42.0 \% ; \mathrm{B}=0.27 \mathrm{mg} \mathrm{dm}^{-3} ; \mathrm{Cu}=1.4 \mathrm{mg} \mathrm{dm}^{-3} ; \mathrm{Fe}=$ $68.0 \mathrm{mg} \mathrm{dm}^{-3} ; \mathrm{Mn}=7.7 \mathrm{mg} \mathrm{dm}^{-3} ;$ and $\mathrm{Zn}=1.4 \mathrm{mg}$ $\mathrm{dm}^{-3}$. Based on this analysis the need for liming was determined, using $50 \%$ for the $\mathrm{V}_{2}$ formula of liming calculation of according Werner et al. (1997). Liming involved using $245,52 \mathrm{mg}$ vaso $^{-1}$ of $\mathrm{CaO}$ and $142,56 \mathrm{mg} \mathrm{vaso}^{-1}$ of $\mathrm{MgO}$ and after liming, the soil was moistened and incubated for 30 days.

Five application rates for phosphorus $(0,15$, 30,45 , and $60 \mathrm{mg} \mathrm{dm}^{-3}$ of $\mathrm{P}_{2} \mathrm{O}_{5}$ ) were used and five application rates for calcium $(0,20,40,60$, and 80 $\mathrm{mg} \mathrm{dm}{ }^{-3}$ of $\mathrm{Ca}^{2+}$ ) combined in a surface response study based on a central experimental design modified through fractionated factorial $5^{2}$, based on Littell; Mott (1975) (Figure 1). Thus, 13 combinations of different application rates of phosphorus $\left(\mathrm{P}_{2} \mathrm{O}_{5}\right)$ and calcium $\left(\mathrm{Ca}^{2+}\right)$ were used (in $\mathrm{mg} \mathrm{\textrm {dm } ^ { - 3 }}$ ): $0-0 ; 0-40 ; 0-80 ; 15-20 ; 15-60 ; 30-0 ; 30-$ $40 ; 30-80 ; 45-20 ; 45-60 ; 60-0 ; 60-40$; and 60-80. The experimental design was arranged in randomized blocks, with four replications.

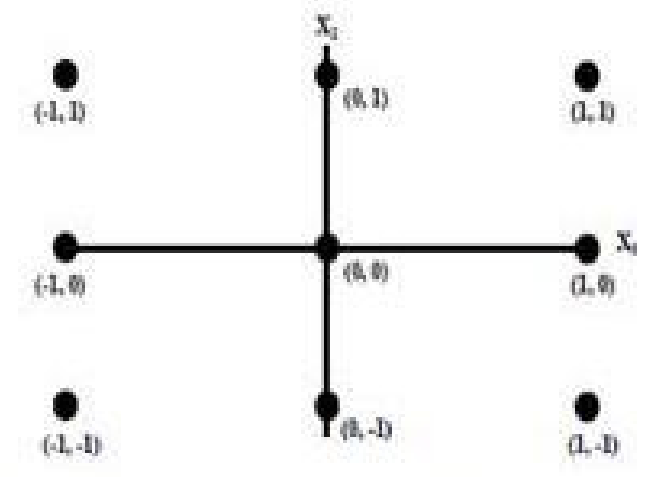

Figure 1. Central experimental design modified through fractionated factorial $5^{2}$ (LITTELL; MOTT, 1975).

After the soil incubation period, thirty seeds of the Macrotyloma legume were sown per pot. Soon after sowing the micronutrient molybdenum and combined rates of phosphorus and calcium that corresponded to the treatments were applied. In treatments without calcium and phosphorus only distilled water was provided. Phosphorus was supplied as sodium phosphate $\left(\mathrm{NaH}_{2} \mathrm{PO}_{4}\right)$ and calcium as calcium chloride $\left(\mathrm{CaCl}_{2}\right)$. The other nutrients, potassium $(\mathrm{KCl})$, sulphur $\left(\mathrm{H}_{2} \mathrm{~S}_{3} \mathrm{O}_{4}\right)$, zinc $\left(\mathrm{ZnCl}_{2}\right)$, copper $\left(\mathrm{CuCl}_{2} \cdot \mathrm{H}_{2} \mathrm{O}\right)$, and boron $\left(\mathrm{H}_{3} \mathrm{BO}_{3}\right)$ were supplied on alternate days. 
Fourteen days after sowing the Macrotyloma legume, the plants were thinned until seven plants remained per pot. Two harvests of the plants were performed, the first 53 days after sowing the legume and the second 34 days after the first harvest. The plants were harvested at a height of $5 \mathrm{~cm}$ from soil surface. Soon after the first harvest, the treatments were reapplied, as well as the other nutrients previously reported.

All the material harvested was oven-dried using forced air circulation at $65^{\circ} \mathrm{C}$ until constant weight was achieved. Dried leaves and branches were ground separately in a Wiley mill for evaluation of the bromatological characteristics: neutral detergent fiber assayed without a heat-stable amylase and expressed inclusive of residual ash (NDF; VAN SOEST et al.,1991), acid detergent fiber expressed inclusive of residual ash (ADF; VAN SOEST et al.,1991; CAMPOS et al., 2016); lignin (ROBERTSON; VAN SOEST, 1981); hemicellulose (hemicellulose $=\mathrm{NDF}-\mathrm{ADF}$; CAMPOS et al., 2016), cellulose (cellulose $=$ ADF lignin; Campos et al., 2016) and crude protein (CP: $\mathrm{N}\left(\mathrm{g} \mathrm{kg}^{-1}\right) \times 6.25$; JONES, 1931).

After chemical evaluations, all data were subjected to statistical analysis, with response surface analysis using the Statistical Analysis System (SAS, 2000), and $P \leq 0.05$ indicating statistical significance. First analysis of variance was performed with the combinations of $\mathrm{P}$ and $\mathrm{Ca}$ at different application rates, which were significant in the F-test for the $\mathrm{P} \times \mathrm{Ca}$ interactions; polynomial regression (response surface) was performed using the RSREG procedure. When this interaction was not significant, a first and second degree regression study was performed using the GLM procedure for the effect of phosphorus and calcium rates alone.

\section{RESULTS}

Evaluating the bromatological characteristics in the first and second harvests of the Macrotyloma legume, it was observed that ADF, hemicellulose, cellulose, and lignin contents of the leaves did not show isolated or combined responses to phosphorus and calcium rates. In the first harvest, the average ADF, hemicellulose, cellulose, and lignin content of the leaves of the Macrotyloma legume were $172 \mathrm{~g} \mathrm{~kg}^{-1}$ of DM, $167 \mathrm{~g} \mathrm{~kg}^{-1}$ of DM, $112 \mathrm{~g} \mathrm{~kg}^{-1}$ of $\mathrm{DM}$, and $46 \mathrm{~g} \mathrm{~kg}^{-1}$ of $\mathrm{DM}$, respectively. In the second harvest, the average $\mathrm{ADF}$, hemicellulose, cellulose, and lignin content of in the leaves were $173 \mathrm{~g} \mathrm{~kg}^{-1}$ of DM, $125 \mathrm{~g} \mathrm{~kg}^{-1}$ of $\mathrm{DM}, 114 \mathrm{~g} \mathrm{~kg}^{-1}$ of $\mathrm{DM}$, and $55 \mathrm{~g} \mathrm{~kg}^{-1}$ of $\mathrm{DM}$, respectively.
The ADF, NDF, and lignin content in the case of branches of the Macrotyloma legume did not show isolated or combined responses to phosphorus and calcium rates in the first and second harvests. In the first harvest, the average ADF, NDF, and lignin content of the branches were $477 \mathrm{~g} \mathrm{~kg}^{-1}$ of DM, 623 $\mathrm{g} \mathrm{kg}^{-1}$ of DM, and $88 \mathrm{~g} \mathrm{~kg}^{-1}$ of DM, respectively. In the second harvest, the average $\mathrm{ADF}, \mathrm{NDF}$, and lignin content of the branches were $538 \mathrm{~g} \mathrm{~kg}^{-1}$ of $\mathrm{DM}, 689 \mathrm{~g} \mathrm{~kg}^{-1}$ of $\mathrm{DM}$, and $97 \mathrm{~g} \mathrm{~kg}^{-1}$ of $\mathrm{DM}$, respectively. The lack of response of the bromatological characteristics to phosphorus and calcium rates in the second harvest may be related to the harvest interval in this study.

The NDF content of the leaves showed an isolated response to phosphorus and calcium rates only in the first harvest of the Macrotyloma legume. With regard the phosphorus rates, the results of NDF in the leaves were adjusted to the quadratic regression model, and the phosphorus rate at 31.47 $\mathrm{mg} \mathrm{dm}{ }^{-3}$ was responsible for the lowest NDF content ( $319 \mathrm{~g} \mathrm{~kg}^{-1}$ of DM) (Figure 2A). In the case of calcium the NDF content of the leaves was adjusted to the linear regression model, with higher NDF content as the calcium application rate increased (Figure 2B). The NDF content of the leaves as a function of increased calcium application rates ranged from 317 to $337 \mathrm{~g} \mathrm{~kg}^{-1}$ of DM.

The hemicellulose content of the branches in both harvests and the cellulose content of the branches only in the second harvest responded to different the phosphorus application rates. In the first harvest, the hemicellulose content of the branches was adjusted to the linear regression model with decrease in this content of $5.96 \%$ (151 to $142 \mathrm{~g}$ $\mathrm{kg}^{-1}$ of DM) as the phosphorus rates increase (Figure $3 \mathrm{~A})$.

In the second harvest, the hemicellulose content is adjusted to the quadratic regression model and the phosphorus rate at $26,9 \mathrm{mg} \mathrm{dm}^{-3}$ revealed a higher value (156 g kg-1 of DM) (Figure 3B). The hemicellulose corresponds to the cell wall fraction that is most easily digested by the animals.

With regard to the cellulose content of the branches in the second harvest, it was observed that, as the phosphorus application rates increased, there was an increase in these values, ranging from 425 to $444 \mathrm{~g} \mathrm{~kg}^{-1}$ of DM depending on the increase in the phosphorus rates (Figure 3C). 
(B)
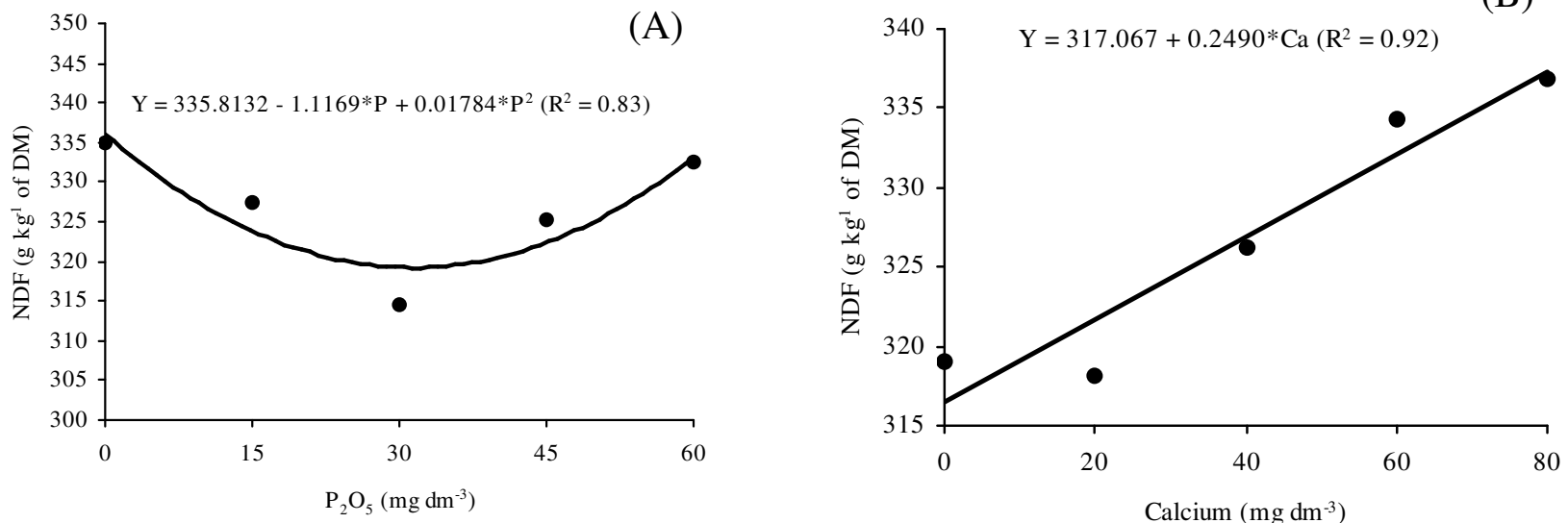

Figure 2. Neutral detergent fiber (NDF) in the leaves as a function of the phosphorus application rates (A) and calcium application rates (B) and the Macrotyloma legume in the first harvest.
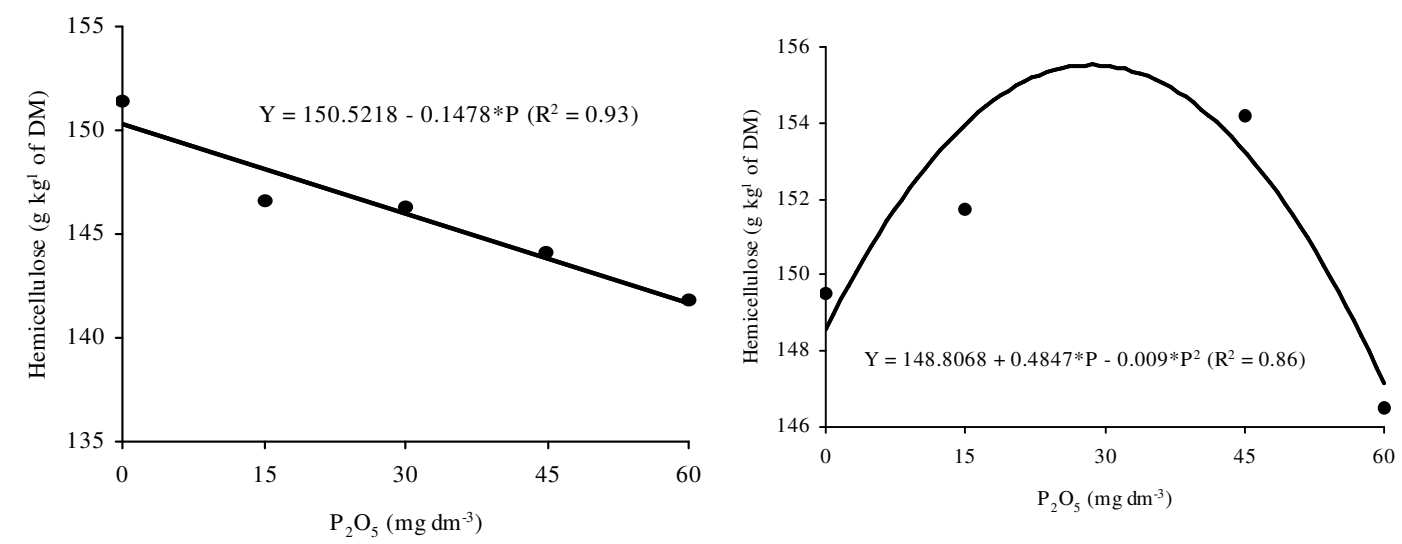

(B)

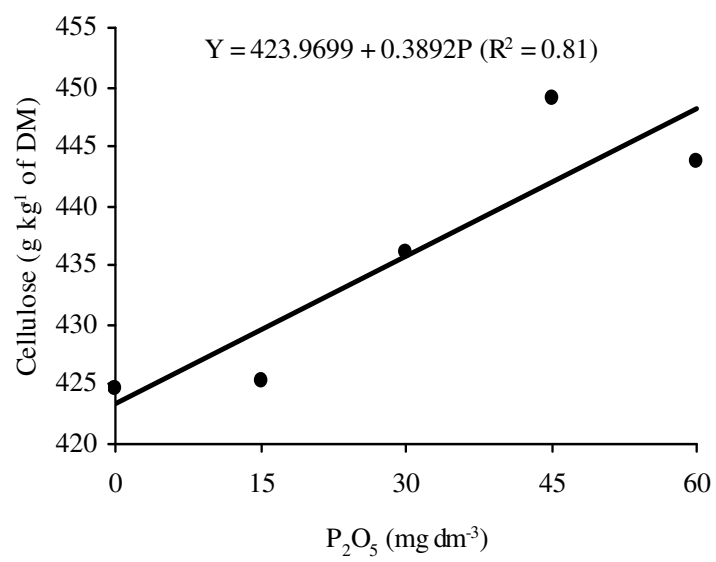

(C)

Figure 3. Hemicellulose content of the branches in the first cut (A) and hemicellulose content (B) and cellulose content $(\mathrm{C})$ in the second harvest, with different phosphorus application rates.

Regarding the CP content of the leaves and branches, responses to phosphorus rates were observed only in the first harvest. In the leaves, the $\mathrm{CP}$ content in the first harvest was adjusted to the linear regression model, with a reduction in these values as the phosphorus rates increased (Figure 4A). The CP content ranged from 172 to $132 \mathrm{~g} \mathrm{~kg}^{-1}$ of $\mathrm{DM}$ as a result of increased phosphorus application rates. Although there were negative changes in $\mathrm{CP}$ content depending on the phosphorus

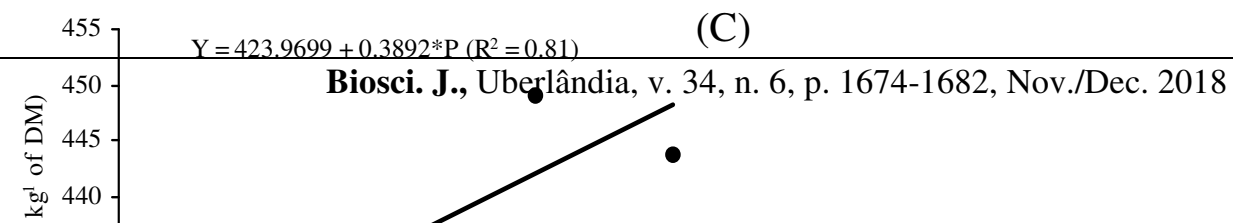


supply, the values observed could meet the daily $\mathrm{CP}$ requirements of animals. In the branches, the $\mathrm{CP}$ content in the first harvest was adjusted to the quadratic regression model, and the phosphorus rate at $39.6 \mathrm{mg} \mathrm{dm}^{-3}$ showed a lower $\mathrm{CP}$ content $(88 \mathrm{~g}$ $\mathrm{kg}^{-1}$ of DM) (Figure 4B). Based on these results, it was found that the $\mathrm{CP}$ content of the leaves was higher compared to the branches. The consumption of branches by ruminants is generally lower than that of leaves, due to their lower nutritional value.

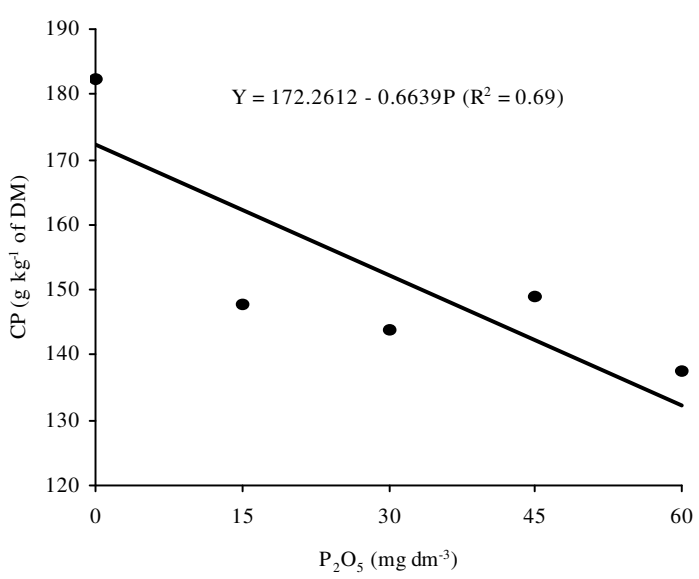

(A)

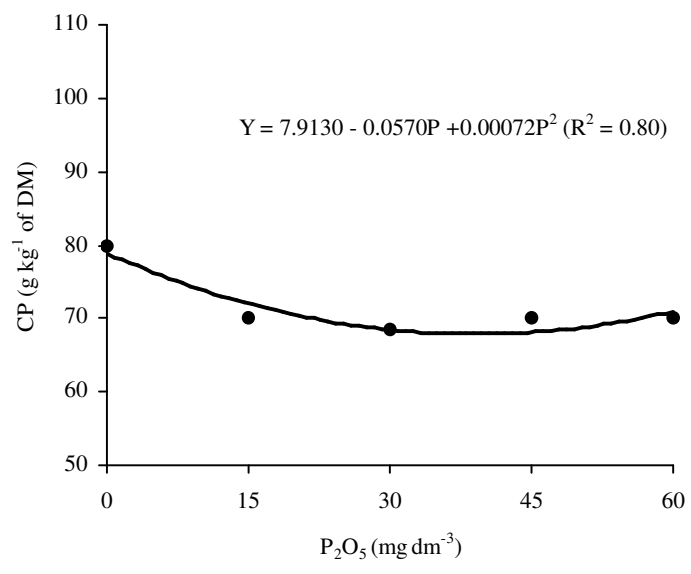

(B)

Figure 4. Crude protein content of the leaves (A) and of the branches (B) in the first harvest with different phosphorus application rates

\section{DISCUSSION}

The NDF content of the leaves of the Macrotyloma legume depended on phosphorus application rates and indicated the requirement for sufficient amounts of phosphorus in the soil (TÜRK et al., 2009), since feed consumption is negatively correlated with NDF, i.e. the slower the degradation, the longer the forage remains in the rumen and consequently, limits the intake of forage (DU et al., 2016). Calcium negatively interfered with the NDF content of legume leaves, since high NDF content can affect feed intake by ruminants because it limits feed intake as a result its slow fractional degradation rate and its low passage rate through the ruminal environment, something which can compromise the productive performance of animals (MONÇÃO et al., 2016). The NDF content is related to consumption modulation, energety density of food, mastication, passage rate, and digestibility of food (VAN SOEST, 1991; EDOUARD et al., 2008). Besides, FDN and ADF fractions are the least digestible fraction of plants and, in the case of plant leaves, the optimal situation would be having low levels of these fractions (TEIXEIRA et al., 2010).

The NDF content of the leaves of the Macrotyloma legume that were reported in this study, both in relation to the isolated phosphorus 
supply and in relation to the isolated calcium supply, are below the levels observed by Teixeira et al. (2010) for the legumes Calopogonium muconoides, Desmodium hetero-carpon, Arachis pintoi, Pueraria phaseoloides, Stylosanthes guianensis cv. Bandeirante, cv. Cook and cv. Mineirão, and Stylosanthes macrocephala cv. Pioneiro.

Hemicellulose and cellulose levels in the Macrotyloma legume, depending on the phosphorus application rates, behaved in an opposite way to what is preferred for feeding ruminants, since higher hemicellulose content and lower cellulose content are interesting, considering that bacterial flora into rumen break these components into short chain fatty acids (SCFAs), mainly the acetic, propionic, and butyric acid, which represent the most important source of energy in animals that are fed a forage based diet (PARIZ et al., 2011).

The hemicellulose content observed in the branches of the Macrotyloma legume in this study in relation to the isolated supply of phosphorus is below the levels observed by Teixeira et al. (2010) for the legumes Arachis pintoi, Calopogonium muconoides, Clitoria ternatea, Desmodium heterocarpon, Pueraria phaseoloides and Stylosanthes guianensis cv. Bandeirante, cv. Cook and cv. Mineirão. In the second harvest, the average values of cellulose in the branches were three times higher than the average hemicellulose content, being even higher than those observed by Teixeira et al. (2010) for the legumes Arachis pintoi, Calopogonium muconoides, Desmodium hetero-carpon, Pueraria phaseoloides, Stylosanthes guianensis cv.
Bandeirante, cv. Cook and cv. Mineirão and Stylosanthes macrocephala cv. Pioneiro.

The CP content of the leaves and branches of the Macrotyloma legume depending on the phosphorus rates of application, would not limit animal production. PB content below $70 \mathrm{~g} \mathrm{~kg}^{-1}$ of DM limits animal production, as it promotes decreased voluntary consumption, lower digestibility coefficients, and negative nitrogen balance (KOSCHECK et al., 2013). The high CP content in foraging species favours voluntary consumption by the animals (EVITAYANI et al., 2004).

\section{CONCLUSIONS}

The combined supply of phosphorus and calcium did not influence the nutritional quality of the Macrotyloma legume.

Calcium supply alone influenced only the NDF content of the leaves and in the case of phosphorus the $\mathrm{CP}$ content of the leaves.

Phosphorus application rates of 31.5 $\mathrm{mg} \mathrm{dm}^{-3}$ and $28.2 \mathrm{mg} \mathrm{dm}^{-3}$ were responsible for lower NDF content of the leaves and higher hemicellulose content of the branches, respectively.

\section{ACKNOWLEDGEMENTS}

This work was financially supported by the São Paulo Research Foundation (FAPESP - grant number: 2014/22866-2 "Responses of the Macrotyloma legume to rate combinations of phosphorus and calcium"').

RESUMO: O fornecimento de nutrientes para as leguminosas forrageiras é importante para sua qualidade nutricional. $\mathrm{O}$ estudo objetivou avaliar as características bromatológicas da Macrotyloma axillare em resposta a aplicação combinada de doses de fósforo e cálcio. O estudo foi desenvolvido em uma casa de vegetação sob um Argissolo Vermelho-Amarelo. Utilizou-se um esquema fatorial $5^{2}$ fracionado, com 13 combinações diferentes das doses de fósforo e cálcio (P-Ca): 0-0, 0-40, 0-80, 15-20, 15-60, 30-0, 30-40, 30-80, 45-20, 45-60, 60-0, 60-40, e 60-80 mg dm ${ }^{-3}$. As unidades experimentais foram distribuídas em delineamento de blocos ao acaso, com quatro repetições. Determinou-se fibra em detergente neutro (FDN), fibra em detergente ácido (FDA), hemicelulose, celulose, lignina e proteína bruta (PB) das folhas e ramos em dois cortes. Nos dois cortes da leguminosa observou-se que os teores de FDA, hemicelulose, celulose e lignina das folhas não apresentaram respostas isoladas ou combinadas às doses de fósforo e cálcio. Concluiu-se que o fornecimento combinado de fósforo e cálcio não influenciou na qualidade nutricional da leguminosa. $O$ fornecimento isolado de cálcio interferiu somente no teor de FDN e fornecimento de fósforo na PB das folhas. As doses de fósforo de $31,5 \mathrm{mg} \mathrm{dm}^{-3}$ e $28,2 \mathrm{mg} \mathrm{dm}^{-3}$ foram responsáveis pelo menor teor de FDN nas folhas e pelo maior teor de hemicelulose nos ramos, respectivamente.

PALAVRAS-CHAVE: Agropecuária sustentável. Combinação de nutrientes. Fibras. Leguminosa forrageira. Proteína bruta. 


\section{REFERENCES}

BARROS-RODRÍGUEZ, M.; SANDOVAL-CASTRO, C. A.; SOLORIO-SÁNCHEZ, J.; SARMIENTOFRANCO, L. A.; ROJAS-HERRERA, R.; KLIEVE, A. V. Leucaena leucocephala in ruminant nutrition. Tropical and Subtropical Agroecosystems, Mérida, v. 17, n. 2, p. 173-183, 2014.

BLUMENTHAL, M. J.; STAPLES, L. B. Origin, evaluation and use of Macrotyloma as forage - a review. Tropical Grassland - Forrajes Tropicales, Cali, v. 27, n. 16, p. 16-29, 1993.

CAMPOS, F. P.; NICÁCIO, D. R. O.; SARMENTO, P.; CRUZ, M. C. P.; SANTOS, T. M.; FARIA, A. F. G.; FERREIRA, M. E.; CONCEIÇÃO, M. R. G.; LIMA, C. G. Chemical composition and in vitro ruminal digestibility of hand-plucked samples of Xaraes palisade grass fertilized with incremental levels of nitrogen.

Animal Feed Science and Technology, Amsterdam, v. 215, p. 1-12, 2016.

https://doi.org/10.1016/j.anifeedsci.2015.12.013

CHAUDHRY, A. S. Forage based animal production systems and sustainability, an invited keynote. Revista Brasileira de Zootecnia, Viçosa, v. 37, no.spe, p. 78-84, 2008.

CHEN, H. Chemical Composition and Structure of Natural Lignocellulose. In: CHEN, H. (Ed.). Biotechnology of lignocellulose: theory and practice. Dordrecht: Springer Netherlands, 2014. p. 25-71.

https://doi.org/10.1007/978-94-007-6898-7_2

https://doi.org/10.1007/978-94-007-6898-7

DU, S.; XU, M.; YAO, J. Relationship between fibre degradation kinetics and chemical composition of forages and by-products in ruminants. Journal of Applied Animal Research, United Kingdom, v. 44, n. 1, p. 189-193, 2016. https://doi.org/10.1080/09712119.2015.1031767

EDOUARD, N.; FLEURANCE, G.; MARTIN-ROSSET, W.; DUNCAN, P.; DULPHY, J.; GRANGE, S.; BAUMONT R.; DUBROEUCQ H.; PEREZ-BARBERIA F. J; GORDON, I. Voluntary intake and digestibility in horses: Effect of forage quality with emphasis on individual variability. Animal, v. 2, n. 10, p. 1526-1533, 2008. https://doi.org/10.1017/S1751731108002760

EVITAYANI, L.; WARLY, A.; FARIANI, T.; ICHINOHE, S. A.; ABDULRAZAK, A.; FUJIHARA, T. Comparative rumen degradability of some legume forages between wet and dry season in West Sumatra, Indonesia. Asian-Australasian Journal of Animal Sciences, Seoul, v. 17, n. 8, p. 1107-1111, 2004. https://doi.org/10.5713/ajas.2004.1107

GEE, G.W.; BAUDER, W. Particle-size analysis. In: BLACK C.A. (Ed.). Methods of soil analysis. Madison: American Society of Agronomy, p. 545-567, 1996.

JONES, D. B. Factors for converting percentages of nitrogen in foods and feeds into percentagens of protein. Washington: US Department of Agriculture, 1931. p. 01-22 (Circular, $\mathrm{n}^{\circ}$ 183).

KOSCHECK, J. F. W.; ZERVOUDAKIS, J. T.; ZERVOUDAKIS, L. K. H.; CABRAL, L. S.; OLIVEIRA, A. A.; BENATTI, J. M. B.; CARVALHO, D. M. G.; SILVA, R. P. Total digestible nutrient levels in supplements for finishing steers in the rainy season: nutritional characteristics and microbial efficiency. Revista Brasileira de Zootecnia, Viçosa, v. 42, n. 11, p. 798-805, 2013.

LITTELL, R.C.; MOTT, G.O. Computer assisted design and analysis of response surface experiments in agronomy. Soil and Crop Society of Florida Proceedings, Florida, v. 34, n.1, p. 94-97, 1975.

LÜSCHER, A.; MUELLER-HARVEY, I.; SOUSSANA, J. F.; REES, R. M.; PEYRAUD, J. L. Potential of legume-based grassland-livestock systems in Europe: a review. Grass and Forage Science, New Jersey, v. 69, n. 2, p. 206-228, 2014. https://doi.org/10.1111/gfs.12124 
MONÇÃO, F. P.; REIS, S. T.; RIGUEIRA, J. P. S.; SALES, E. C. J.; ALVES, D. D.; AGUIAR, A. C. R.; OLIVEIRA, E. R.; ROCHA JÚNIOR, V. R. Ruminal degradation of dry matter and neutral detergent fiber of banana peel treated with limestone. Semina: Ciências Agrárias, Londrina, v. 37, n. 1, p. 345-356, 2016. https://doi.org/10.5433/1679-0359.2016v37n1p345

OLIVO, C. J.; ZIECH, M. F.; MEINERZ, G. R.; AGNOLIN, C. A.; TYSKA, D.; BOTH, J. F. Valor nutritivo de pastagens consorciadas com diferentes espécies de leguminosas. Pesquisa Agropecuária Brasileira, Brasília, v. 38, n. 8, p. 1543-1552, 2009. https://doi.org/10.1590/S1516-35982009000800019

PARIZ, C. M.; AZENHA, M. V.; ANDREOTTI, M. A.; MELLO, F. C.; ULIAN, N. A.; BERGAMASCHINE, A. F. Produção e composição bromatológica de forrageiras em sistema de integração lavoura-pecuária em diferentes épocas de semeadura. Pesquisa Agropecuária Brasileira, Brasília, v. 46, n. 10, p. 1392-1400, 2011. https://doi.org/10.1590/S0100-204X2011001000037

ROBERTSON, J. B.; VAN SOEST, P. J. The detergent system of analysis and its application to humam foods. In: JAMES, W. P. T., THEANDER, O. (Eds.). The analysis of dietary fiber in food. New York: Marcel Dekker, p. 123-158, 1981.

ROSCHER, C.; THEIN, S.; WEIGELT, A.; TEMPERTON, V. M.; BUCHMANN, N.; SCHULZE, E. D. N 2 fixation and performance of 12 legume species in a 6-year grassland biodiversity experiment. Plant and Soil, Netherlands, v. 341, n. 1-2, p. 333-348, 2011. https://doi.org/10.1007/s11104-010-0647-0

SANTOS, H. G.; JACOMINE, P. K. T.; ANJOS, L. H. C.; OLIVEIRA, V. A.; OLIVEIRA, J. B.; COELHO, M. R.; LUMBRERAS, J. F.; CUNHA, T. J. F. Sistema brasileiro de classificação de solos. 2. ed. Rio de Janeiro: Embrapa Solos, 2006. 304 p.

SAS User's Guide: Statistics. Version 8. SAS Institute, 2000.

SARKAR, P.; BOSNEAGA, E.; AUER, M. Plant cell walls throughout evolution: towards a molecular understanding of their design principles. Journal of Experimental Botany, Lancaster, v. 60, n. 13, p. 36153635, 2009. https://doi.org/10.1093/jxb/erp245

SITA, K., SEHGAL, A., HANUMANTHARAO, B., NAIR, R. M., VARA PRASAD, P. V., KUMAR, S., GAUR, P. M.; FAROOQ, M.; SIDDIQUE, K. H. M.; VARSHNEY, R. K.; NAYYAR, H. Food legumes and rising temperatures: effects, adaptive functional mechanisms specific to reproductive growth stage and strategies to improve heat tolerance. Frontiers in Plant Science, Lausanne, v. 8, n. 1658, p. 1-30, 2017. https://doi.org/10.3389/fpls.2017.01658

SULIEMAN, S.; VAN HA, C.; SCHULZE, J.; TRAN, L. S. P. Growth and nodulation of symbiotic Medicago truncatula at different levels of phosphorus availability, Journal of Experimental Botany, Oxford, v.64, n. 10, p. 2701-2712, 2013. https://doi.org/10.1093/jxb/ert122

TEIXEIRA, V. I.; DUBEUX JR., J. C. B.; SANTOS, M. V. F.; LIRA JR., M. DE A.; LIRA, M. DE A.; SILVA, H. M. S. Aspectos agronômicos e bromatológicos de leguminosas forrageiras no Nordeste Brasileiro. Archivos de Zootecnia, Cordoba, v. 59, n. 226, p. 245-254, 2010.

TÜRK, M.; ALBAYRAK, S.; YÜKSEL, O. Effects of fertilisation and harvesting stages on forage yield and quality of hairy vetch (Vicia villosa Roth.). New Zealand Journal of Agricultural Research, Wellington, v. 52, n. 3, p. 269-275, 2009. https://doi.org/10.1080/00288230909510511

VAN SOEST, P. J.; ROBERTSON, J. B.; LEWIS, B. A. Symposium: Carbohydrate methodology, metabolism, and nutritional implications in dairy cattle. Journal of Dairy Science, Champaign, v. 74, n. 1, p. 3583-3597, 1991. https://doi.org/10.3168/jds.S0022-0302(91)78551-2 
WERNER, J. C.; PAULINO, V. T.; CANTARELlA, H.; ANDRADE, N. O.; QUAGGIO, J. A. Forrageiras. In: RAIJ, B. van; CANTARELLA, H.; QUAGGIO, J. A.; FURLANI, A. M. C. (Eds) Recomendações de adubação e calagem para o Estado de São Paulo. Campinas: Instituto Agronômico \& Fundação IAC, p. 261273, 1997.

WHITE, H. J.; BROADLEY, M. R. Calcium in Plants. Annals of Botany, Oxford, v. 92, n. 4, p. 487-511, 2003. https://doi.org/10.1093/aob/mcg164

YANG, J.; PUNSHON, T.; GUERINOT, M. L.; HIRSCHI, K. D. (2012). Plant Calcium Content: Ready to Remodel. Nutrients, Basel, v. 4, n. 8, p. 1120-1136, 2012. https://doi.org/10.3390/nu4081120 